\title{
REPORT OF THE WATER SANITATION (PRIMARY) SURVEY \\ OF PAKTIA PROVINCE
}

Date of mission: From $12,15,1988$ to $12,24,1988$.

Goal of mission: Survey Paktia province for rehabilitation project of Afghanistan.

Members of team: Dr: Anwar, project coordinator. 2. Dr: Sharon McDonnell medical advisor.3- Eng. Sayed Aqa in-country coordinator of engineering project.4- Amin John surveyor. 5- Four commanders from Shwak area of Gardez.

\section{INTRODUCTION:}

Paktia is a mountainous area in the south-east part of Afghanistan. In the south and east Paktia is bordered.with Waziristan and Korm agencies of N.W.F.P of Pakistan. The major product of the area is wood from the forests.

Food is imported from Pakistan and Kabul. In the forests we can find some kind of fruits like, pine nuts, walnuts and mulberry.

There is not a lot of cultivable land in the area that we saw. Drinking water is not healthy and or safe, lots of diseases are caused by the drinking water.

Houses are destroyed about 80 - $90 \%$. Roads are destroyed or mined.

A German project had been working in Paktia province for a long time, before the war. They had done a lot of work in road building, agriculture and forestry.

Current war activity is extensive in Sayed Karam, Gardez, and Khost. This includes bombardment and heavy artillaries. Chawni mjlitary unit in Jaji was captured approximately four months ago. Shar-i-Now area of Chamkani was captured one week after Chawni.

Musa Khile and Jani Khile have been free areas for many years.

Khost city remains under government control, however the rest of district is in the control of Mujahideen.

We visited Chamkani, Musa khile, Jani Khile on our way to Musa Khile, Ahmad Khile and AlIi Khile districts in Jaji and Andwam area in Sayed Karam district.

\section{CHAMKANI DISTRICT:}

GEOGRAPHICAL LOCATION :

North: Ali Khil district (Jaji). East and north-east Pakistan. South : Jani Khil district (Maidan khola). South_east Jaji Maidan district. South-west Sayed Karam district. North-west Ahmad Khil district.

In the recent years Chamkani was divided to two subdistricts: Chamkani and Danda Pattan subdistricts. Now entire 
area known by the most common name Chamkani.

\section{POPULATION :}

Before the war there were about 100,000 people living in the area. Most of the people have refuged to Pakistan.

Currently, about 15,000 people are living in the area. (Numbers are estimated by the community).

\section{AGRICULTURE :}

Most part of the cultivable lands are planted.(See picture \# ). Major products: Wheat, and corn. There were some small orchards before the war, but now the trees are dry due to lack of irrigation. Compared to other districts that we saw, Chamkani has a lot of lands for agriculture and planting. Crops have been planted for spring with maxipack seed.

WATER SYSTEM:

Canals are partly destroyed. Main source of water is snowmelt which comes down from Jaji and Musa khil with two rivers meeting each other in Chamkani near Ster Kelay.

Another source of water are the karizes. The people say there are about 30-35 karizes in the area.

Most of them have been destroyed or neglected. There has been no maintenance or cleaning in the last ten years. I saw three karizes in Dongi valley.

\section{I) Moda Khil karize:}

This is owned by Moda Khil village. Three hundred jarebs lands are irrigated by this karize, the length of the karize is approximately $1.5 \mathrm{~km}$. Its depth in the middle is 29 feet. Its water was used for both drinking and irrigation. All the shaft wells are covered at the top except one. (See picture\#). Estimated cost of repair by the people was Rs. 300,000 for the entire karize.

Specific damage has been caused by bombardment and lack of cleaning since the beginning of the war.

Currently there is no flow of water in this karize.

II) Landi Rogha karize:

This karize is owned by Kheya Khil village, belonging to Mangal tribe.

This karize is irrigating about 300 jarebs of the lands, and has 60 shaft wells. Most of the shaft wells are destroyed because of war. The flow of the water is $144 \mathrm{inch}^{3} / \mathrm{Sec}$, currently. The people of the village were working to clean this karize. They have hired people from Logar and Maidan at a cost of 600 Rs. per meter. Money comes from community.(See picture\#). The length 
of the karize is $1-2 \mathrm{~km}$. The community estimated the cost of repair to be $600,000 \mathrm{Rs}$.

III) Kheya Khil karize.

Located in Sorung Guray village in the southern part of Chamkani. The owner of the karize is Kheya Khil village. The water is used for drinking and irrigation. Lands irrigated by this karize is 300 jarebs. (According to community). The length of the karize is about one $\mathrm{km}$., and has about 50 shaft wells. It has a small pool to store the water.The water is flowing, but people say that the flow of water has decreased, so it needs to be cleaned and repaired. there are no significant damages in this karize. Community estimated cost of repair to be 500,000 Rs.

Beside these two sources, springs are good and quality sources for drinking water.

There is a spring in the mountains near Shar-i-Now, about 600-700 meters away to the north part of the town. The water of this spring was flowing down to a nearby hospital by a 2 inch metal pipe. It was previously providing drinking water for about, 2500 people. In shar-i-Now there is another spring in the same mountains but it is located at a higher point. According to the people, this spring has a lot of water.

There is a deep well near a big former military unit. The well needs to be repaired and there is no pump to take the water out of the well. (See picture\#)

There are a spring and a karize in Nozi village in the western part of the Chamkani. People have a lot of problems getting drinking water because the flow is inadequate. People have to wait for a long time to have water. Even some people are coming during night time to take water from the spring.

During our visit in Chamkani we met a S.C.A.- World Vision team, they have a proposal for $\$ 1.7 \mathrm{million}$ for pilot project for two valleys of Chamkani.

Their initial survey was done in Oct. 1988. At that time they found mines to be a significant problems.

They have included the following in their proposal for funding :

1) Hydrology.

2) Mine clearing.

3) Fertilizer.

4) Seed.

5) Training in black smithing and welding.

6) Agro-Chemicals.

They do not want to be involved in large machinery (tractors), drinking water or construction.

They have field project manager Rahim Shah, as coordinator

for Chamkani

They were planning to speak with the shora the next day. Possibly coordination with them may include utilization of their project for on site training. (See recommendation item 4). 
CONSTRUCTION: CHumkuni Distitit

1) Houses: Most of the houses are built of mud, and wood. there are some buildings made of concrete which belonged to government, including a hospital a school and some governmental nouses. The hospital has a big main building and annexes consisting of about 60 rooms in two floors.

Most doors, windows and wiring have been removed. (Refer to medical report).

Significant destruction of the main building has occurred, estimated $18-20 \%$.

In the western part of Shar-i-Now there are three buildings:

a) A large agricultural store house. This stock was built by a German project, and only small repairs are needed before it can be used.

b) Primary district offices building with two floors . All doors and windows are removed.

c) A building, former school. No one is using the building currently. The school building is almost completely damaged with destruction estimated at $50-60 \%$.

There are some other buildings in which the former military unit was located. Destruction estimated $80-90 \%$ in these buildings.

2) Roads: There are some road in the area unpaved. The construction of the road is not satisfactory. For any type of projects or population expansion the roads need to be repaired. Most of the bridges are damaged some parts of the roads are mined. These two reasons result in the necessity to drive in the stream, mined roads and destroyed bridges.

To drive form Chankani to Musa Khil we had to use the river as the roadway, between Ster Kelay to Surog Guray (approximately one hour). The road is primarily through flat terrain in valleys in the south.

Later we also drove in the stream when we were going to Ahmad khil district from Chamkani toward the west, because the original road was destroyed by the river water and the war. (See recommendation item 2 ).

Need more indepth survey of these roads for cost estimate.

\section{MUSA KHIL AND JANI KHIL DISTRICTS:}

It is a long narrow valley divided into two district, when you pass a high pass in the southern part Chamkani, you enter the valley into Jani Khil which later becomes Musa Khil. The valley is wider in the beginning in Sunzay and Balzay area.

The valley goes from North-East to South-West.

There are about $750-800$ families living in Jani Khil because this area has had no fighting for the last seven years most families have not refuged.

Jani Khil and Musa Khil have less cultivable land in 
Chamkani. Enough irrigation water is available because a river passes through the valley. The problem is with the drinking water, the people use the river water which is not clean and may have to walk long distances to reach the water. In certain areas spring water is available. It is clean near the source of the spring but when it comes down from the mountains it becomes polluted.

Many people have goiter, especially women, which reflects a lack of iodine in the drinking water and soil. We saw a lot of women in Musa Khil 58\% of them had goiters. (See medical report). There was a spring in Ghazak village of Musa Khil district. This spring could provide water only for few families because of small flow.

The people said there is another good spring which has a lot of water, in the mountain $2 \mathrm{~km}$ from the Ghazak village.

In Kagakay village there is a big spring flowing into a stream passing through the center of the village. However it is not a safe way to use spring water. The water should be protected from pollutants.

\section{CONSTRUCTION :}

1) Roads: The road are relatively good there, compared to the other areas. They need to be repaired because of the lack of maintenance over these ten years. They are not safe when there is mud and snow. We had to walk for about 40 minutes to see an IMC clinic in Kagakay village, because we couldn't drive, the road was narrow and snow made it more dangerous. When we got in Jani Khil the road was dry so we could drive on it.

We wanted to go on to Sayed Karam district, the recent snowfall made it impossible to travel in to sayed Karam. Thus we walked back toward Jani Khil for about four hours, and had to push the car in some parts of the road. From Kosin Khola which is a village in jani Khil, we took the car, and drove in to the river where we were stuck two or three times. (See pictures \#

1. In Kawa Khola we were able to drive on the road. In Chamkani we were stuck in mud and had to leave the car.

2) Houses: In Musa Khil the houses are the same as they were before the war with very small damages. But in Jani Khil some houses were damaged because of bombardment, especially in Kandow, Maidan Khola and Balazay villages.

\section{SAYED KARAM DISTRICT:}

\section{ANDWAM AREA :}

\section{GEOGRAPHICAL LOCATION :}

North: Ahmad Khil district.

South: Sayed Karam. East Leja Mangal valley. West: Machalgho. 


\section{POPULATION :}

It is difficult to find how many people are living in the area, people were mentioning completely different numbers.

Since this area was under the control of the communist government until four months ago almost all the people were in their own villages and have not refuged. Ghondi village families had to leave the area and refuged.

AGRICULTURE :

The war has not effected agriculture in this area. Some part of the lands have not been planted for a long time, especially in Ghondi village. Major products of the area are wheat and apricots.

WATER SYSTEM :

1) Irrigation: main sources of water are river and karizes:

In Ghondi village the irrigation system is destroyed about $80 \%$. There is a karize in the eastern part of the village that currently has no flow of water. The karize needs to be repaired.

2) Drinking water: the only source of drinking water in the village is a spring nearby. This spring has a tunnel inside. The spring is covered and has a door in the front to go in and take water. (See picture\#).

CONSTRUCTION :

1) Houses: Andwam is an area with less damage, only four or five houses were bombed in Ghondi village.

2) Roads: There is one main road which connects Jaji to sayed Karam that goes through this area. (See Jaji road's section).

JAJ I

AHMAD KHIL AND JANI KHIL DISTRICTS:

GEOGRAPHICAL LOCATION :

North: Ningarhar province. South - west: Sayed Karam district. South - east: Chamkani. East: Pakistan. west: Logar province. Ahmad Khil is located in southern part and Ali Khil in the northern part of $\mathrm{Jaji}$.

POPULATION :

We were not able to find out how many people were (are) living there. Most are the people have refuged from Ali Khil district. 


\section{AGRICULTURE :}

Lands are in better condition in Ahmad Khil than in

Ali khil. In Ali Khil district the lands are mined and have not been planted since the beginning of the war. But, in Ahmad Khil most of the land has been planted currently. Ali Khil has more cultivable land than Ahmad Khil area.

\section{WATER SYSTEM:}

1) Irrigation: Main source of the water is snow melt in a river which is passing through this area, and going to Chamkani. Canals are in better condition in Ahmad Khil district. In Ali Khil, there was a big military unit called Chawni, so there was a lot of heavy fighting which caused a lot of damage in the area, including the water system.

2) Drinking water: Before the war they were using springs, wells and river water for drinking, but now the only source of drinking water is the river. Springs need to be repaired. There are two springs in Ali Khil district near Chawni. Until four months ago a governmental military unit was there which used these springs as the main sources of drinking water. Now there is no flow of water, only a small pool full of water is in the front of each spring.

They dug some wells in Ahmad Khil but most of them are destroyed, the people in the area say, that it is very difficult to dig wells, because the land is rocky.

I did not see any particular spring in Ahmad Khil, when I asked if there are some springs in the area, the answer was positive, and the people were pointing toward the mountains surrounding the area. They said that there are some springs about 1 - $2 \mathrm{~km}$ from the villages which need work on them to let the water flow down.

\section{CONSTRUCTION :}

1) Houses: Ali Khil is a district with a lot of damage. Most of the village like Gul Ghondi, Jadran kelay, Sharif kaley, Khazi Khil and Hashim Khil are completely destroyed . There was a big military unit and governmental district offices in the area of Chawni. All buildings have received damages and some of them were extensively damaged. There was a small hospital, a school and some other governmental buildings with small damages that need to be repaired.

Ahmad Khil district is an area with a lot of mines. These are located on the top of the mountains around the villages. llouses have received small damages. It is possible to live in such houses with some inconveniences.

2) Roads: Roads need to be repaired urgently. The road here provides an important main road between Teree Mangal, the 
border, Logar and Kabul provinces, passing Ali Khil district. Another road connects Gardiz to Jaji, this road goes through Ahmad Khil and sayed Karam districts. There is a pass also in this road which is called Naray Kotal. This pass separates Ahmad Khil district from Ali Khil district. There was a bridge near Lar Lewanay village in Ali Khil district which is destroyed because of bombardment.

In some parts, along the road we had to drive into the river because the roads are destroyed. From Ahmad Khil toward

Sayed Karam we had to drive into the stream near shwat village. On the same road when you are going to go to Teree Mangal, you have to drive two or three times in the stream.

NOTE: Some other main problems of the area concerning to the engineering project are also included in the content of this report. 


\section{RECOMMENDATIONS}

1) Rehabilitation Project of Afghanistan (RPA) should be started by offering small cheap projects. First, it gives us a chance to know the area very well and to know the people with whom we are working. To understand the administration and management of such people.

Second these small projects will introduce IRC to the community more quickly, without the lag time or risks of longer projects.

2) In my opinion, engineering project should be started with repairing roads in Chamkani, and providing drinking water in any of the areas. There are two reasons for selecting Chamkani:

I) It is a central area in Paktia, form which we can get to Jani Khil, Musa Khil, Jaji Maidan, Sayed Karam, Jaji and Khost very easily if we have good roads. (See Chamkani map).

The most important roads which need to be repaired are:

1) The road from Chankani to Jani Khil.

2) The road form Chamkani to Ahmad Khil (Jaji).

II) In this season of the year Chamkani has more favorable climate compared to other areas.

3) Surveyors should be trained from all provinces in which IRC wants to work. Each team should consist of a mixture from all provinces. Do not need a separate team for each province. This way balances the bias towards home region with the positive of familiarity with region.

It is also one of the ways to absorb them for long-term employment. The same team can survey all the provinces that we want to work in. In this way we will save the time for training separate teams for each province.

We should retrain them for other projects to survey, because they are familiar with the area, they have experience doing survey, and we also will not repeat some subjects, like math. and geography in each training course.

4) It is of great value to coordinate with other crossborder agencies. We must learn of their plans as well as their experiences and share our own plans. If possible coordinate in some projects. For example, World Vision is planning to work in Chamkani. They want to work on agriculture and mine clearing. Need to follow-up with them here in Peshawar since mine clearing will be very important for our projects also.

5) People are cutting trees from the forests. Many trucks full of wood are moving toward Pakistan every day. Deforestation should be controlled or compensed through local authorities as possible. One of the ways to compensate deforestation is to provide trees for planting by the people in the area. 